\title{
Factors associated with self-reported non- completion of the hepatitis $B$ vaccine series in men who have sex with men in Brazil
}

\author{
Artur Acelino Francisco Luz Nunes Queiroz ${ }^{1}$, Álvaro Francisco Lopes de Sousa ${ }^{1,2^{*}}$, Matheus Costa Brandão Matos ${ }^{3}$, \\ Telma Maria Evangelista de Araújo ${ }^{3}$, Sandra Brignol ${ }^{4}$, Renata Karina Reis ${ }^{1}$, Elucir Gir ${ }^{1}$ and \\ Maria Eliete Batista Moura ${ }^{3}$
}

\begin{abstract}
Background: The objective of the present study was to analyze the factors associated with non-completion of the hepatitis B vaccine series among men who have sex with men and use geosocial dating apps in Brazil.

Methods: This was a cross-sectional, population survey-based, analytical study, conducted exclusively online in all the regions of Brazil, with a sample of 1855 men who have sex with men. The data was collected between November 2016 and February 2017, using the social networking website Facebook.

Results: Univariate, bivariate and multivariate analyses showed that $4.7 \%$ of the participants reported receiving one dose of the vaccine, $12.5 \%$ two doses, $19.4 \%$ three doses, and $45.8 \%$ did not know. Multivariate analysis showed that level of education ( $\mathrm{OR}=0.31 ; \mathrm{Cl} 95 \% 0.14-0.72 ; p=0.007)$, identification as bisexual $(\mathrm{OR}=0.6$; $\mathrm{Cl}$ 95\% 0.38-0.95; $p=0.030$ ), HIV serological status (OR:2.3; Cl 95\% 1.58-3.34; $p=<0.001$ ) and frequency of access to health services $(\mathrm{OR}=2.38 ; \mathrm{Cl} 95 \%$ 1.53-3.72; $p=<0.001)$ were associated with not completing the vaccine series. Low completion of the hepatitis B vaccine series was detected in the population studied.
\end{abstract}

Conclusion: Completion of the hepatitis B vaccine series was low among men who have sex with men and use geosocial dating apps in Brazil. The factors associated with non-completion were related to social, individual and healthcare (programmatic) vulnerabilities.

Keywords: Hepatitis B, Vaccines, Men who have sex with men, Social networks, Vulnerabilities, Geosocial networking phone applications

\section{Background}

Infection by the hepatitis B virus (HBV) continues to be a major health problem. Its estimated prevalence is two billion people worldwide, with associated subclinical and clinical manifestations. Among those who are infected, around 240 million are chronically infected and have a higher risk of incurring serious hepatitis-related complications, such as cirrhosis and hepatocellular carcinoma [1].

\footnotetext{
* Correspondence: alvarosousa@usp.br

${ }^{1}$ Ribeirão Preto College of Nursing, University of São Paulo, Campus Universitário, Avenida dos Bandeirantes, 3900, Bairro Monte Alegre, Ribeirão Preto, SP 14040-902, Brazil

${ }^{2}$ Global Health and Tropical Medicine, GHTM, Instituto de Higiene e Medicina Tropical, IHMT, Universidade Nova de Lisboa, UNL, Lisbon, Portugal

Full list of author information is available at the end of the article
}

The hepatitis B virus is transmitted in two ways: vertically (mother-child transmission) and horizontally, through exposure to contaminated blood or other body fluids, especially through unprotected sexual relations, which is the most common form of exposure [2]. Among the population groups considered highly vulnerable to $\mathrm{HBV}$, men who have sex with men (MSM) stand out for their high prevalence of hepatitis B (15.4\%), according to a population survey conducted with this group in Brazil [3].

The vulnerability of MSM to the virus is associated with a higher frequency of several factors, such as engaging in unprotected anal sex, multiple partners, a history of sexually transmitted diseases (STDs), stigma, violence, and difficulty accessing health services [3, 4]. 
In Brazil, the primary method for prevention is vaccination, which has been provided since the end of the 1990s for children and higher-vulnerability groups. At present, it is universal, through a vaccination series based on three doses. All the vaccination programs focus on the administration of the complete series of doses. However, protective antibody levels are developed after one dose of the vaccine in 30 to $50 \%$ of those who are vaccinated, and in $75 \%$ after two doses $[5,6]$.

Although free protection against the virus is ensured at the primary health level, difficulties accessing health services may contribute to low or even incomplete vaccination coverage, especially among vulnerable populations [7]. Based on this scenario, and also in view of the scarcity of Brazilian studies that address HBV immunization in the MSM population, the aim of the present study was to analyze the factors associated with non-completion of the hepatitis B vaccine series among men who have sex with men and use geosocial dating apps in Brazil.

\section{Methods}

This study is part of a multicenter study entitled "Behaviors, practices, and vulnerabilities among men who have sex with men and use geolocation (geosocial) dating apps in Brazil." It encompassed all of Brazil's regions and sought to examine the behaviors and practices of men who have sex with men and use geosocial dating apps, and their vulnerability to HIV, hepatitis B and C, and syphilis.

This was a cross-sectional, epidemiological, survey-based, analytical study, since it involved a large contingent of MSM from various states in Brazil, which enabled obtaining primary information on the health status of this group. The study was conducted among MSM who use geosocial dating apps for sexual encounters. The data was collected exclusively online, which promoted the participation of MSM from cities of different sizes and those further away from large urban centers, unlike large epidemiological studies that have previously been carried out with MSM in Brazil, but which have focused on large urban centers and state capitals [8].

\section{Sample}

The sample was calculated based on the estimated MSM population $(3.5 \%$ of the overall population of men in Brazil [9]) - an estimate widely used in surveys with this population. The sample size calculation took into consideration a maximum permissible error of $5 \%$ and a significance level of $5 \%$ in the event of a decision to reject the main hypotheses of the analysis [10], and the final sample was fixed in 1855 participants.

\section{Study protocol}

The data was collected between November 2016 and February 2017, using only the Facebook social networking website to publicize the survey. A fixed post was written on a Facebook page (https://www.facebook.com/taafimdeque/), which was administered by the two researchers responsible for the data collection and provided not only information on the research but also information related to STDs. Only this fixed post with a link to the study was boosted by the researchers. The post also had an invitation for people to participate and it was continually boosted (weekly) to have access to all of Brazil's regions, which made it possible to reach the necessary sample size to meet the study objectives. The use of the boost feature is a valuable tool for reaching difficult-to-access populations, since it enables highlighting online content or pages. This type of approach attracts the attention of users and increases the number of views.

The post was accompanied by a hyperlink that provided access to the survey questionnaire, with obligatory and optional questions, which was subdivided into four sections in order to obtain social, demographic and health information on the participants: (1) Personal characteristics; (2) Sociocultural characteristics; (3) Health issues; and (4) Sexual practices. The system was designed so that it would only be possible to move to a new section only if all the obligatory question, selected by the researchers, had been answered; this way, the questionnaire would only be tallied at the end if all the conditions had been satisfied. Therefore, incomplete questionnaires were not saved. To respond to the questionnaire, the participants needed to provide their email, to avoid duplication of responses. The inclusion criteria were: identifying oneself as a cisgender man; being 18 years of age or older; having sexual relation with another man in the last 12 months; and having used apps for sexual encounters at least once in the last 30 days. Users not residing in Brazil were excluded.

The description of the outcome (hepatitis $B$ vaccine history) was self-reported by the participants, since the researchers did not have access to vaccine dose records through immunization booklets; however, the participants were instructed to check their booklets before answering. A person was considered vaccinated if the series (three doses) had been completed and recorded in the immunization booklet; not completely vaccinated if they had received "one or two doses"; and not vaccinated in the case of "zero doses" or the "I don't know" response option, as per recommendations from the Brazilian Ministry of Health [11].

For analyses in the logistical model, the information was regrouped into a) complete series - participants who reported receiving three vaccine doses; and b) those who had received less than three doses (one or two doses) or did not know how many doses they had received, defined as an incomplete series, according to the definitions established by the Brazilian Ministry of Health [11]. 


\section{Data analysis}

The data was entered on a Microsoft Excel for Windows worksheet and imported afterward into the data analysis program. The Kolmogorov-Smirnov test was used to assess the normality distribution of the numerical variables (age, income, and length of time of relationship). To describe the factors of interest, descriptive analyses were performed for both the numerical variables and the categories.

For univariate analysis and analysis of the association between immunization status and categorized vulnerability factors, the chi-square test and Fisher's exact test were used, with a significance level of 0.05 . To build the confidence intervals, a confidence of $95 \%$ was used, with the help of the Statistical Package for the Social Sciences (SPSS) IBM $^{\oplus}$ Version 23.0.

Univariate and multivariate logistic regression generated the Odds Ratio (OR) and adjusted OR, indicating the odds of non-completion of the hepatitis $B$ vaccine series. The reference categories were: elementary education for education; heterosexual for sexual orientation; HIV positive for serological status; seeking information from health professionals; seeking information online; and higher frequency of use of health services. This made it possible to verify the odds of negative events such as risk factors and, as protectors, the factors that lead to better care and, thus, less likelihood of not completing the hepatitis B vaccine series.

\section{Ethical aspects}

The study was approved by the Research Ethics Committee (Opinion No. 1523003) and strictly complied with all the ethical precepts in Resolution 466/12, with guidelines for research with human subjects in Brazil. The participants read the free and informed consent form online and then signed it, thereby indicating their agreement with the proposed objectives and willingness to participate in the study. This consent was applied and obtained online.

\section{Results}

Among the participants $(n=1855), 4.7 \%$ reported having received one dose, $12.5 \%$ two doses and $19.4 \%$ three doses, thus, $36,6 \%$ of participants report some type of protection. Another $17.6 \%$ reported not having been vaccinated (zero doses), and $45.8 \%$ did not know how many doses they had received, as shown in Table 1.

The average age of the participants was 25.7 years old, with a standard deviation of 7.8 years. The majority had completed their higher education (57.8\%); did not practice any religion (63.9\%); lived with their parents (55.5\%); were single (75.2\%); and engaged in casual sexual relationships (49.3\%). Majority of the participants lived in the southeast region of Brazil (50.3\%) (Table 1).
Table 2 presents the bivariate analysis of the factors associated with completion of the hepatitis $B$ vaccine series among the study participants. In this analysis, association with the study outcome was statistically significant for the following factors: education ( $p<0.001)$; Brazilian region of residence $(p=0.023)$; sexual orientation $(p<0.001)$; marital status $(p=0.011)$; presence of STDs $(p=0.003)$; HIV status $(p<0.001)$; use of alcohol during sex $(p=0.003)$; and frequency of use of health services $(p<0.001)$.

Multivariate analysis (Table 3 ) indicated that the odds of non-completion of the hepatitis $B$ vaccine series were high among those with less than university level education: those with secondary education $(\mathrm{OR}=3.8 ; \mathrm{CI}$ $95 \%=2.6-5.7)$, or less $(\mathrm{OR}=3.2$; CI $95 \%=1.4-7.4)$, had the worst outcomes. In relation to HIV serological status, being HIV negative $(\mathrm{OR}=2.3$; CI 95\% = 1.6-3.3) and not knowing one's status (OR =3.7; CI $95 \%=2.3-5.8)$ increased the likelihood of an incomplete vaccine series. In terms of access to health information and services, not seeking information from health professionals increased the probability of an incomplete vaccine series $(\mathrm{OR}=1.5$ : CI $95 \%=1.1-1.9)$, while searching for another source of information other than the internet proved to be a protection factor for the occurrence of an incomplete vaccine series $(\mathrm{OR}=0.4$; CI 95\% $=0.3-0.6)$. Another result worth noting was related to seeking health services; the lower the frequency, the higher the odds of an incomplete vaccine series; the worst scenario was those who rarely seek health services $(\mathrm{OR}=2.38$; CI 95\% $=1.53$ 3.72). Sexual identity was retained in the model, even though it had no statistical significance, since it improved adjustment quality in the presence of other factors, and also indicated higher protection in the bisexual category $(\mathrm{OR}=0.6$; CI 95\% = 0.4-1.0) (Table 3).

\section{Discussion}

Self-reported completion of the hepatitis B vaccine series was low among MSM who participated in the study (19.4\%), compared to the number of third doses accumulated in the Brazilian adult population, which was $49.3 \%$ according to recent official data [12]. These low rates are cause for concern because they occurred in a population with higher exposure to risk factors for hepatitis B virus infection [12]. Thus, this situation seems to worsen in the case of vulnerable populations, such as MSM. The findings of our study indicated that most were not fully vaccinated, were unable to prove vaccination or were unaware of their vaccination status. These percentages were also lower than the vaccination rates reported in other studies conducted exclusively with MSM, which varied between 50.7\% [13] and 77.4\% [14], even with self-reporting [13] as the data collection method. 
Table 1 Sociodemographic characteristics of men who have sex with men and use geosocial dating apps in Brazil. ( $n=1855)$

\begin{tabular}{|c|c|c|c|c|c|c|}
\hline Factor of interest/vulnerability & $\mathrm{N}$ & $\%$ & Mean & SD & $\mathrm{Cl}(95 \%)$ & Min-Max \\
\hline Age (in years) & & & 25.74 & 7.76 & $(21.0-21.8)$ & $18-90$ \\
\hline 18 to 20 & 522 & 23.2 & & & & \\
\hline 21 to 25 & 836 & 37.1 & & & & \\
\hline 26 to 30 & 488 & 21.7 & & & & \\
\hline Over 30 & 376 & 16.7 & & & & \\
\hline \multicolumn{7}{|l|}{ Education } \\
\hline Elementary Education & 57 & 2.5 & & & & \\
\hline Secondary Education & 445 & 19.7 & & & & \\
\hline University & 1303 & 57.8 & & & & \\
\hline Postgraduate & 445 & 19.7 & & & & \\
\hline \multicolumn{7}{|l|}{ Region of residence } \\
\hline North & 108 & 4.8 & & & & \\
\hline Northeast & 336 & 14.9 & & & & \\
\hline Center-West & 202 & 9 & & & & \\
\hline Southeast & 1133 & 50.3 & & & & \\
\hline South & 424 & 18.8 & & & & \\
\hline \multicolumn{7}{|l|}{ Marital Status } \\
\hline Single & 1696 & 75.2 & & & & \\
\hline Living as married & 516 & 22.9 & & & & \\
\hline Separated/divorced/widowed & 38 & 1.7 & & & & \\
\hline
\end{tabular}

However, our results should be interpreted considering the Brazilian context that, unlike other countries, offers the hepatitis $\mathrm{B}$ vaccine free of charges to children and adolescents since the beginning of the 2000s [15]. Thus, part of our sample, aged between 18 and 19 years, may have been vaccinated (or started the vaccination scheme) by their parents and do not have this information.

The introduction of the hepatitis $B$ vaccine in the Brazilian context has been considered decisive in reducing HBV infection rates, even in the presence of risky sexual behaviors [16], although its universal implementation is recent. Nevertheless, the task of discussing growth or reduction in hepatitis B vaccine coverage is still difficult in the Brazilian context, since there are no studies that define the country's situation in relation to infection and/or vaccination status among MSM.

A number of intrinsic factors may be associated with increased vulnerability of MSM to hepatitis B virus infection, such as sociocultural characteristics and sexual behavior, as well as external factors related to difficulty accessing health services, denial of basic LGBT health rights and institutionalized homophobia [17].

As an example, low proportions of hepatitis B vaccination were reported by younger MSM, even though this population has more access to information than the adult population [18]. In contrast, those who were over 40 had a higher proportion of hepatitis B vaccination, a finding also noted in other studies involving MSM $[3,18,19]$.

The predominance of individuals with higher education levels and a higher rate of complete vaccine series (57.8\%) corroborates the higher odds of non-completion in participants with only secondary or elementary education. This would indicate that level of education is related to the search for protection and has a direct impact on the percentage of new cases of hepatitis $B$ [3].

HIV-seropositive individuals and those with a history of other STDs presented a higher vaccination percentage (16.2 and $15.1 \%$, respectively), a result complemented by multivariate analysis, which demonstrated that individuals who were unaware of their HIV status were four times more likely to present an incomplete vaccine series. This finding was also reported by other studies that have investigated this population $[20,21]$.

The association between completion of the vaccine series and a previous STD diagnosis suggests that in the presence of infection, MSM seek to be vaccinated, since during their visit to a specialized health service, screening refers them for further testing and vaccination [20].

The participants who reported going to health units more frequently had a better vaccination history, 
Table 2 Bivariate analysis of factors associated with completion of the vaccine series for men who have sex with men and use geosocial dating apps in Brazil $(n=1855)$

\begin{tabular}{|c|c|c|c|c|c|c|c|}
\hline \multirow[t]{3}{*}{ Variables } & \multicolumn{4}{|c|}{ Complete Series } & & & \multirow{3}{*}{$p$-value* } \\
\hline & \multicolumn{2}{|l|}{ Yes } & \multicolumn{2}{|l|}{ No } & \multicolumn{2}{|l|}{ Total } & \\
\hline & $n$ & $(\%)$ & $n$ & (\%) & $n$ & (\%) & \\
\hline Education & & & & & & & $<0.001^{*}$ \\
\hline Secondary Education & 46 & 13.2 & 303 & 86.8 & 349 & 100 & \\
\hline University & 231 & 21.3 & 856 & 78.7 & 1087 & 100 & \\
\hline Postgraduate & 152 & 59.0 & 219 & 41.0 & 371 & 100 & \\
\hline Region of residencet & & & & & & & $0.023^{*}$ \\
\hline North & 12 & 14.5 & 71 & 85.5 & 83 & 100 & \\
\hline Northeast & 59 & 21.9 & 211 & 78.1 & 270 & 100 & \\
\hline Center-West & 56 & 31.5 & 122 & 68.5 & 178 & 100 & \\
\hline Southeast & 207 & 22.4 & 717 & 77.6 & 924 & 100 & \\
\hline South & 95 & 26.4 & 265 & 73.6 & 360 & 100 & \\
\hline Sexual Orientation† & & & & & & & $<0.001^{*}$ \\
\hline Heterosexual & 25 & 14.3 & 148 & 85.7 & 173 & 100 & \\
\hline Homosexual & 368 & 26.0 & 1047 & 74.0 & 1415 & 100 & \\
\hline Bisexual & 43 & 16.5 & 217 & 83.4 & 260 & 100 & \\
\hline Marital Status & & & & & & & $0.005^{*}$ \\
\hline Single & 320 & 22.8 & 1084 & 77.2 & 1404 & 100 & \\
\hline Stable relationship & 117 & 25.9 & 334 & 74.1 & 451 & 100 & \\
\hline Had an STD in the last 12 months & & & & & & & $0.003^{*}$ \\
\hline Yes & 66 & 29.6 & 157 & 70.4 & 223 & 100 & \\
\hline No & 352 & 23.5 & 1143 & 76.5 & 1495 & 100 & \\
\hline I don't know & 19 & 13.9 & 118 & 86.1 & 137 & 100 & \\
\hline HIV status & & & & & & & $<0.001^{*}$ \\
\hline $\mathrm{HIV+}$ & 71 & 47.7 & 78 & 52.3 & 149 & 100 & \\
\hline HIV- & 304 & 24.9 & 918 & 75.1 & 1222 & 100 & \\
\hline I don't know & 62 & 12.8 & 422 & 87.2 & 484 & 100 & \\
\hline Prevention via condom*** & & & & & & & 0.097 \\
\hline Yes & 405 & 23.5 & 1315 & 76.5 & 1720 & 100 & \\
\hline No & 32 & 23.7 & 103 & 76.3 & 135 & 100 & \\
\hline Use of alcohol during sex ${ }^{* * *} \dagger$ & & & & & & & $0.003^{*}$ \\
\hline Yes & 205 & 24.0 & 648 & 76.0 & 853 & 100 & \\
\hline No & 229 & 23.0 & 766 & 77.0 & 995 & 100 & \\
\hline Use of illicit drugs during sex***† & & & & & & & 0.338 \\
\hline Yes & 94 & 22.8 & 318 & 77.2 & 412 & 100 & \\
\hline No & 318 & 77.2 & 1100 & 76.2 & 1418 & 100 & \\
\hline Frequency of visits to health services & & & & & & & $<0.001^{*}$ \\
\hline Monthly & 68 & 31.8 & 146 & 68.2 & 214 & 100 & \\
\hline 2 months & 68 & 27.9 & 176 & 72.1 & 244 & 100 & \\
\hline 6 months & 163 & 26.9 & 442 & 73.1 & 605 & 100 & \\
\hline Annually & 87 & 24.3 & 271 & 75.7 & 358 & 100 & \\
\hline Rarely & 51 & 11.8 & 383 & 88.2 & 434 & 100 & \\
\hline
\end{tabular}


Table 2 Bivariate analysis of factors associated with completion of the vaccine series for men who have sex with men and use geosocial dating apps in Brazil $(n=1855)$ (Continued)

\begin{tabular}{|c|c|c|c|c|c|c|c|}
\hline \multirow[t]{3}{*}{ Variables } & \multicolumn{4}{|c|}{ Complete Series } & & & \multirow{3}{*}{$p$-value* } \\
\hline & \multicolumn{2}{|l|}{$\overline{Y e s}$} & \multicolumn{2}{|l|}{ No } & \multicolumn{2}{|l|}{ Total } & \\
\hline & $\bar{n}$ & (\%) & $\bar{n}$ & (\%) & $\bar{n}$ & $(\%)$ & \\
\hline \multicolumn{8}{|l|}{ Health information source } \\
\hline Health professional & & & & & & & $<0.001^{*}$ \\
\hline Yes & 309 & 28.6 & 770 & 71.4 & 1079 & 100 & \\
\hline No & 128 & 16.5 & 648 & 83.5 & 776 & 100 & \\
\hline Family member & & & & & & & 0.515 \\
\hline Yes & 24 & 21.1 & 90 & 78.9 & 114 & 100 & \\
\hline No & 413 & 23.7 & 1328 & 76.3 & 1741 & 100 & \\
\hline Television & & & & & & & $0.032^{*}$ \\
\hline Yes & 19 & 15.6 & 103 & 84.4 & 122 & 100 & \\
\hline No & 418 & 24.1 & 1315 & 75.9 & 1733 & 100 & \\
\hline Internet & & & & & & & $<0.001^{*}$ \\
\hline Yes & 339 & 79.0 & 1272 & 79.0 & 1611 & 100 & \\
\hline No & 98 & 40.2 & 146 & 59.8 & 244 & 100 & \\
\hline Testing and counseling center & & & & & & & $<0.001^{*}$ \\
\hline Yes & 117 & 30.9 & 262 & 69.1 & 379 & 100 & \\
\hline No & 320 & 21.7 & 1156 & 78.3 & 1476 & 100 & \\
\hline Testing location & & & & & & & $0.006^{*}$ \\
\hline Yes & 61 & 31.4 & 133 & 68.6 & 194 & 100 & \\
\hline No & 376 & 22.6 & 1285 & 77.4 & 1661 & 100 & \\
\hline
\end{tabular}

*Statistical significance was set at 0.05; **Fisher's exact test; ***30 days prior to the survey

+ Value of $n$ differs due to it not being required to answer the question

compared to those who went occasionally (or rarely), which increases the odds of an incomplete vaccine series. This finding demonstrates the importance of health units being prepared to receive LGBT individuals, particularly at the primary care level, since it is the main gateway to the Unified Health System [22]. This result is further supported by evidence that not seeking information from health professionals increases the odds of non-completion of the vaccine series. This reinforces the argument that a structure that drives away the LGBT community worsens their access to the health system and, consequently, vaccination coverage [23].

Because of the growth of STDs among vulnerable populations [24], initiatives and interventions must be reformulated to reduce these populations' exposure to these infections. As this population does not usually attend health services, tailored strategies implemented in places frequented by MSM could significantly improve vaccination rates. The use of technologies, especially geosocial apps, could serve as a channel to access the MSM population and disseminate information and health services for their use $[25,26]$.
Our study shows that the factors associated with completion of the hepatitis B vaccine series included social, individual, and programmatic (healthcare) vulnerabilities [27]. Thus, our study provides unprecedented results among MSM, more specifically among users of geosocial dating apps, in relation to vaccination status.

\section{Limitations}

The findings of this study are subject to limitations. The main limitation of this study stands on the fact that it was based on self-reported information by the participants. This information is subject to memory bias, in the absence of vaccination records for verification. To mitigate this limitation, the participants were instructed to consult their vaccination records.

Additionally, the three-dose schedule of the anti-hepatitis $B$ vaccine over a period of months may make it more difficult to remember than other single dose vaccines [28].

Last, it is not possible to generalize these findings to the entire Brazilian MSM population, since the interviewees represented a sample of individuals who used a specific technology for finding sexual partners. 
Table 3 Multivariate analysis of factors associated with completion of the vaccine series for men who have sex with men and use geosocial dating apps in Brazil $(n=1855)$

\begin{tabular}{|c|c|c|c|c|}
\hline Factor analyzed & Crude OR & $\mathrm{Cl}(95 \%)^{*}$ & Adjusted OR & $\mathrm{Cl}(95 \%)^{*}$ \\
\hline \multicolumn{5}{|l|}{ Education } \\
\hline Postgraduate & 1.0 & & 1.0 & \\
\hline University & 2.6 & $(2.0-3.3)$ & 2.4 & $(1.9-3.2)$ \\
\hline Secondary Education & 4.6 & $(3.2-6.6)$ & 3.8 & $(2.6-5.7)$ \\
\hline Elementary Education & 3.5 & $(1.6-7.6)$ & 3.2 & $(1.4-7.4)$ \\
\hline \multicolumn{5}{|l|}{ Sexual Orientation } \\
\hline Heterosexual & 1.0 & & 1.0 & \\
\hline Homosexual & 0.8 & $(0.5-1.5)$ & 0.8 & $(0.5-1.5)$ \\
\hline Bisexual & 0.6 & $(4.1-9.4)$ & 0.6 & $(0.3-0.9)$ \\
\hline \multicolumn{5}{|l|}{ HIV status } \\
\hline $\mathrm{HIV+}$ & 1.0 & & 1.0 & \\
\hline HIV- & 2.7 & $(1.9-3.9)$ & 2.3 & $(1.6-3.3)$ \\
\hline I don't know & 6.2 & $(4.1-9.4)$ & 3.7 & $(2.3-5.8)$ \\
\hline \multicolumn{5}{|l|}{ Health information source } \\
\hline \multicolumn{5}{|l|}{ Health professional } \\
\hline Yes & 1.0 & & 1.0 & \\
\hline No & 2.0 & $(1.6-2.6)$ & 1.5 & $(1.1-1.9)$ \\
\hline \multicolumn{5}{|l|}{ Internet } \\
\hline Yes & 1.0 & & 1.0 & \\
\hline No & 0.4 & $(0.3-0.5)$ & 0.4 & $(0.3-0.6)$ \\
\hline
\end{tabular}

Frequency of visits to health services

\begin{tabular}{lllll} 
Monthly & 1.0 & & 1.0 & \\
2 months & 1.2 & $(0.8-1.8)$ & 1.4 & $(0.9-2.2)$ \\
6 months & 1.3 & $(0.9-1.8)$ & 1.4 & $(1.0-2.0)$ \\
Annually & 1.5 & $(1.0-2.1)$ & 1.3 & $(0.9-1.9)$ \\
Rarely & 3.5 & $(2.3-5.3)$ & 2.4 & $(1.5-3.7)$ \\
\hline
\end{tabular}

*Confidence Interval (95\%)

\section{Conclusion}

Completion of the hepatitis $\mathrm{B}$ vaccine series was low among men who have sex with men and use geosocial dating apps in Brazil. The factors associated with noncompletion were level of education, identification as bisexual, HIV serological status, use of the Internet and health professionals as sources of health information, and frequency of use of health services.

The MSM population is classified as vulnerable to sexually transmitted diseases, since they are more exposed to these infections, including HBV infection. This underscores the need for studies at the national level that address this problem and are able to help provide a clearer overview of the health status (physical and mental) of this population. It is recommended that future studies focus on the use of mobile apps as an environment for campaigns, carrying out interventions through the application itself.

\section{Abbreviations}

$\mathrm{Cl}$ : Confidence interval; HBV: Hepatitis B virus; HIV: Human Immunodeficiency Virus; LGBT: Lesbian, gay, bi and/or trans; MSM: Men who have sex with men OR: Odds Ratio; STDs: Sexually transmitted diseases

\section{Acknowledgments}

We would like to thank Dr. Miyeko Hayashida of the University of São Paulo for her support for this project.

\section{Funding}

Coordination for the Improvement of Higher Education Personnel (CAPES).

Availability of data and materials

All data and materials are available upon request.

\section{Authors' contributions}

AAFLNQ and AFLS contributed to the conception and design of the study, data collection, analysis and interpretation, writing of the article and successive reviews. TMEA and SB contributed to the conception and design of the study, data interpretation, writing of the article and successive reviews. MCBM, RKR, EG and MEBM contributed to the conception of the study, data analysis and interpretation, writing of the article and successive reviews. All authors read and approved the final manuscript.

\section{Ethics approval and consent to participate}

The development of this study complied with national and international standards of ethics in research involving human subjects, and was approved by the human research ethics Committee of the Ribeirão Preto College of nursing, as per report 1,523,003

The participants read the free and informed consent form online and then signed it, thereby indicating their agreement with the proposed objectives and willingness to participate in the study. This consent was applied and obtained online, according to national laws regarding research with human participants.

\section{Consent for publication}

Not applicable.

\section{Competing interests}

The authors declare that they have no competing interests.

\section{Publisher's Note}

Springer Nature remains neutral with regard to jurisdictional claims in published maps and institutional affiliations.

\section{Author details}

${ }^{1}$ Ribeirão Preto College of Nursing, University of São Paulo, Campus Universitário, Avenida dos Bandeirantes, 3900, Bairro Monte Alegre, Ribeirão Preto, SP 14040-902, Brazil. ${ }^{2}$ Global Health and Tropical Medicine, GHTM, Instituto de Higiene e Medicina Tropical, IHMT, Universidade Nova de Lisboa, UNL, Lisbon, Portugal. ${ }^{3}$ Federal University of Piauí, Teresina, Brazil. ${ }^{4}$ Collective Health Institute, Fluminense Federal University, Niterói, Brazil.

Received: 29 May 2018 Accepted: 9 April 2019

Published online: 23 April 2019

\section{References}

1. World Health Organization. Hepatitis B fact sheet. World Health Organization: Geneva; 2015. Available from: http://www.who.int/ mediacentre/factsheets/fs204/en/. Accessed 14 Apr 2019.

2. Chonwattana W, Raengsakulrach B, Holtz TH, Wasinrapee P, Tongtoyai J, Chaikummao S, et al. Hepatitis B vaccination uptake and correlates of serologic response among HIV-infected and uninfected men who have sex with men (MSM) in Bangkok. Thailand Vaccine. 2016;34(17):2044-50.

3. Oliveira MP, Matos MAD, Silva ÁMC, Lopes CLR, Teles SA, Matos MA, et al. Prevalence, risk behaviors, and Virological characteristics of hepatitis B virus infection in a Group of men who Have sex with men in Brazil: results from a respondent-driven sampling survey. PLoS One. 2016;11(8):e0160916.

4. Centers for Disease Control and Prevention. Lesbian, Gay, Bisexual, and Transgender Health, 2015. Atlanta, GA: CDC. Available from: http://www.cdc. gov/lgbthealth/youth.htm. Accessed 14 Apr 2019. 
5. Nelson NP, Easterbrook PJ, McMahon BJ. Epidemiology of hepatitis B infection and impact of vaccination on disease. Clin Liver Dis. 2016;20:607-28.

6. Gusmão BM, Pereira FS, Rocha AP, Silva FMB, Dias OV, Costa SDM. Sociodemographic analysis of reported hepatitis $B$ and immunization against the disease. Rev pesqui cuid fundam (Online). 2017;9(3):627-33.

7. Rocon PC, Rodrigues A, Zamboni J, Pedrini MD. Difficulties experienced by trans people in accessing the unified Health system. Cienc saúde coletiva. 2016;21(8):2517-26.

8. Baptista CJ, Dourado I, Andrade TM, Brignol S, Bertoni N, Bastos FI, Brazilian Multicity Study Group on Drug Misuse. HIV Prevalence, Knowledge, Attitudes, and Practices Among Polydrug Users in Brazil: A Biological Survey Using Respondent Driven Sampling. AIDS and Behavior. 2017; 1-15.

9. Ministério da Saúde (BR). Programa Nacional de DST e aids. Pesquisa de Conhecimentos, Atitudes e Práticas na População (PCAP) Brasileira de 15 a 64 ano, 2008. Brasília: Ministério da Saúde, 2011. Available from: http://bvsms.saude.gov.br/bvs/publicacoes/pesquisa_conhecimentos_ atitudes_praticas_populacao_brasileira.pdf. Accessed 14 Apr 2019.

10. Levine DM, Berenson ML, David S. Estatística: teoria e aplicações usando Microsoft Excel em Português. Rio de Janeiro: LTC; 2000.

11. Ministério da Saúde (BR). Secretaria de Vigilância em Saúde. Departamento de Vigilância das Doenças Transmissíveis. Manual de normas e procedimentos para vacinação. Brasília: Ministério da Saúde; 2014.

12. Brasil. Coberturas vacinais no Brasil Período: 2010-2014. Brasília, 2015. Available from: http://portalarquivos2.saude.gov.br/images/pdf/2017/agosto/ 17/AACOBERTURAS-VACINAIS-NO-BRASIL\%2D\%2D-2010-2014.pdf. Accessed 14 Apr 2019

13. Wielding $\mathrm{S}, \mathrm{Ma}$ AH, Clutterbuck DJ. An audit of hepatitis B vaccination for men who have sex with men before and after sexual health service integration. Int J STD AIDS. 2016;27:898-900.

14. Truong HHM, Fatch RTD, McFarland W. Hepatitis B vaccination and infection prevalence among men who have sex with men who travel internationally. Sex Transm Dis. 2018;45(5):e25-8.

15. Brasil. Programa Nacional de Imunizações: 30 anos. Ministério da Saúde. Available from: http://bvsms.saude.gov.br/bvs/publicacoes/livro_30_anos_pni.pdf. Accessed 14 Apr 2019.

16. Ropero Álvarez AM, Pérez-Vilar S, Pacis-Tirso C. Progress in vaccination towards hepatitis $B$ control and elimination in the region of the Americas. BMC Public Health. 2017;17(1):325. https://doi.org/10.1186/s12889-017-4227-6.

17. Nadarzynski T, Smith H, Richardson D, Bremner S, Llewellyn C. Men who have sex with men who do not access sexual health clinics nor disclose sexual orientation are unlikely to receive the HPV vaccine in the UK. Vaccine. 2018;36(33):5065-70. https://doi.org/10.1016/j.vaccine.2018.06.075.

18. Ximenes RAA, Figueiredo GM, Cardoso MRA, Stein AT, Moreira RC, Coral G, et al. Population-based multicentric survey of hepatitis B infection and risk factors in the north, south, and southeast regions of Brazil, 10-20 years after the beginning of vaccination. Am J Trop Med Hyg. 2015;93(6):1341-8.

19. Brazilian Ministry of Health. National Policy for comprehensive Health of lesbians, gays, bisexuals, transvestites and transsexuals. Brasília: Ministry of Health; 2010.

20. Pitasi MA, Bingham TA, Sey EK, Smith AJ, Teshale EH. Hepatitis B virus (HBV) infection, immunity and susceptibility among men who have sex with men (MSM), Los Angeles, county. USA AIDS Behav. 2014;18:248-55.

21. Vet $R$, Wit JB, Das E. Factors associated with hepatitis $B$ vaccination among men who have sex with men: a systematic review of published research. Int J STD AIDS. 2017;28(6):534-42.

22. Brazil. Ministry of Health. Letter of the rights of healthcare users. Brasilia: Ministry of Health, 2007.

23. Albuquerque GA, Lima GC, Silva QG, Alves MJH, Belém JM, Santos FFW, et al. Access to health services by lesbian, gay, bisexual, and transgender persons: systematic literature review. BMC Int Health Hum Rights. 2016; 16(1):2.

24. Joint United Nations Programme on HIV/AIDS (UNAIDS). UNAIDS DATA 2017 [Internet]. Geneva: UNAIDS; 2017. Available from: http://www.unaids. org/sites/default/files/media_asset/20170720_Data_book_2017_en.pdf. Accessed 14 Apr 2019

25. Queiroz AAFLN, Sousa AFL, Matos MCB, Moura MEB, Araujo TME, Reis RK. Knowledge about HIV/AIDS and implications of establishing partnerships among hornet ${ }^{\oplus}$ users. Rev Bras Enferm. 2018;71(4):1949-55.

26. Queiroz AAFLN, Sousa AFL, Araújo TM, Oliveira FB, Moura MEB, Reis RK. a review of risk behaviors for HIV infection by men who have sex with men through geosocial networking phone Apps. J Assoc Nurses AIDS Care. 2017:S1055-3290.

27. Ayres JRCM, França JI, Calazans GJ, Saletti FHC. O conceito de vulnerabilidade e as práticas de saúde: novas perspectivas e desafios. In: Czeresnia D, Freitas CM (orgs.) Promoção da saúde: conceitos, reflexões, tendências. Rio de Janeiro: Fiocruz, 2003;121-144.

28. Neighbors K, Oraka C, Shih L, Lurie P. Awareness and utilization of the hepatitis $B$ vaccine among young men in the Ann Arbor area who have sex with men. J Am Coll Heal. 1999:47:173-8.

\section{Ready to submit your research? Choose BMC and benefit from:}

- fast, convenient online submission

- thorough peer review by experienced researchers in your field

- rapid publication on acceptance

- support for research data, including large and complex data types

- gold Open Access which fosters wider collaboration and increased citations

- maximum visibility for your research: over $100 \mathrm{M}$ website views per year

At BMC, research is always in progress.

Learn more biomedcentral.com/submissions 